\title{
Effects of weed management practices on yield and economics of black gram (Phaseolus mungo)
}

\author{
Kavita D. Rajput*, J. P. Bholane, A.S. Latkar and V. M. Bhale \\ Dr. Panjabrao Deshmukh Krishi Vidyapeeth, Akola (M.S.) India \\ (Email: rajput.kavi13@rediffmail.com)
}

\begin{abstract}
A field investigation was carried out during Kharif season in 2010 at Agronomy Department Farm, Dr.Panjabrao Deshmukh Krishi Vidyapeeth, Akola,to evaluate the effect of four herbicides (imazethapyr, pendimethalin,fenoxyprop-p-ethyl and quizalofop -p-ethyl) applied at different rates with different time of application (pre-emergence,post emergence and combination of both) and cultural practices on weeds.The experiment was laid out in randomized block design replicated three times with thirteen treatments. The results revealed that the application of Pendimethalin @ $1.5 \mathrm{~kg}$ a.i./ha as pre-emergence application recorded lowest weed dry weight (2.01), Higher Weed control efficiency (87.42), Lowest weed index (20.46) and significantly higher yield (10.02q/ha),followed by Pendimethalin @ $1.0 \mathrm{~kg}$ a.i./ha as pre-emergence application and twice hand weeding on 15 and 30 days after sowing (DAS).Among all the weed control treatments, weed free treatment recorded highest (48410 Rs/ha and $35356 \mathrm{Rs} / \mathrm{ha}$ ) gross monetary returns and relative net monetary returns in black gram. Pre-emergence application of pendimethalin @ $1.5 \mathrm{~kg} / \mathrm{ha}(29368)$ as well as @ $1.0 \mathrm{~kg} / \mathrm{ha}$ (29570) and post emergence application of fenoxyprop-p-ethyl @ $0.125 \mathrm{~kg} / \mathrm{ha}(29502)$ followed by cultural practices of two hand weedings at 15 and 30 days after sowing (24607) were found effective in increasing the seed yield and relative net monetary returns of black gram. Benefit : cost ratio was observed highest under post-emergence application of fenoxyprop-p-ethyl @ $0.125 \mathrm{~kg} / \mathrm{ha}(4.10)$ among all the weed control practices.
\end{abstract}

Key Words : Weed flora, WCE, WI, Imazethapyr, Pendimethalin,Fenoxyprop-p-ethyl, Quizalofop-p-ethyl, Yield, Black gram,Economics of practices

View Point Article : Rajput, Kavita D., Bholane, J.P., Latkar, A.S. and Bhale, V.M. (2021). Effects of weed management practices on yield and economics of black gram (Phaseolus mungo). Internat. J. agric. Sci., 17 (AAEBSSD) : 142-146, DOI:10.15740/HAS/IJAS/17-AAEBSSD/ 142-146. Copyright@2021: Hind Agri-Horticultural Society.

Article History : Received : 15.07.2021; Revised : 18.07.2021; Accepted : 23.07.2021

\section{INTRODUCTION}

Black gram (Phaseolus mungo) is one of the important pulse crop grown in the rainfed farming system through out the India.It is the second most important pulse crop covering $31,00,000$ ha $(16.28 \%)$ area in the country.It has high nutritive value and consist high content of proteins, vitamins and minerals. During Kharif (monsoon) season the weeds emerge along with the crop due to favourable environment condition and the crop suffers heavy loss from unchecked weeds particularly in the initial stage of its growth (Vats and Sawhney,1983).In the later stage ,however ,the black

\footnotetext{
* Author for correspondence :
} 
gram offers good competition (Ali et al., 1982). Overall effect is that the weeds caused grain yield losses up to $50 \%$ or even more (Sharma and Nayital, 1991). The conventional method of weed control through cultural practices i.e. Hand weeding, Hoeing is not only too expensive but at times it is not feasible due to wet soil conditions prevailing during rainy season. So, the use of new selective herbicides (pendimethalin,fenoxypropp-ethyl,Imazethapyr and quizalofop-p-ehtyl) with cultural practices in legumes can be effective and economical for controlling the broad spectrum of annual grassy and broad leaf weeds (Yadav et al.,1983). Considering the prevailing cost of laborers and inputs required for weed control treatments, economics were worked out and apart from growth and yield attributes, the nature of yield response to weed management in accordance with its economics determines the feasibility of adoption of the technology by growers. With these objectives the present investigation was therefore undertaken to develop an effective and feasible weed control practice with its higher economic returns in black gram raised under rainfed conditions.

\section{Material AND Methods}

The experiment was undertaken (conducted) on the Research farm of Agronomy Department, Dr. Panjabrao Deshmukh Krishi Vidyapeeth (Dr.PDKV), Akola during Kharif season of 2010. The soil of the experimental field was clay loam with $\mathrm{pH} 7.8,0.55 \%$ organic carbon, 234.58 $\mathrm{kg} /$ ha available $\mathrm{N}, 20.86 \mathrm{~kg} / \mathrm{ha}$ available $\mathrm{P}_{2} \mathrm{O}_{5}$ and 322.94 $\mathrm{kg} / \mathrm{ha}$ available $\mathrm{K}_{2} \mathrm{O}$. The experiment was conducted in a randomised block design replicated three times with thirteen treatments comprising cultural and chemical weed control methods with weed free and weedy check treatments were also included.

The number of weeds present in one square meter area and dry weight of weeds in each plot was counted and measuredat 15, 30, 45, 60 DAS and at harvest. These weeds were further classified into sedges, grasses and broad-leaved weeds. The weeds were uprooted from the destructive sampling area of one $\mathrm{m}^{2}$ and were oven dried to a constant weight at $60^{\circ} \mathrm{C}$ and the dry weight of weeds was expressed in $\mathrm{g}$ per $\mathrm{m}^{2}$. Weed control efficiency at harvest and weed index after harvest of different treatments were computed based on the formula suggest by Gautam et al. (1975) and Gill and Vijaykumar in (1969). Data on grain yield was recorded after harvest.

\section{Weed control efficiency (\%):}

Weed control efficiency was calculated by the help of formula:

$\mathrm{WCE}=(\mathrm{X}-\mathrm{Y} / \mathrm{X}) * \mathbf{1 0 0}$

where, $\mathrm{X}$ : Weed dry matter production in weedy plot.

Y: Weed dry matter production in treated plot.

\section{Weed index (\%):}

Weed index indicates the extent of reduction in yield due to weed competition. It was worked out for different treatments by adopting the formula:

Weed index $=(A-B / A) * 100$

where, A: seed yield of the best treatment,

B: seed yield of the particular treatment for which the index is computed.

\section{Gross monetary returns (GMR):}

The total values of produce i.e. grain yield and straw yield was estimated as per prevailing market rate and treated as gross monetary returns and expressed as Rs./ ha.

Cost of cultivation was the total of expenditure of all operations in rupees in whole growing season of the crop.

\section{Net monetary returns (NMR):}

Net monetary returns were calculated by subtracting cost of cultivation from gross monetary returns.

\section{Benefit: cost ratio (B:C ratio):}

$$
\text { Benefit : Cost ratio }=\frac{\text { Gross monetary returns }}{\text { Cost of cultivation }}
$$

\section{Results AND DiscuSsion}

The results obtained from the present investigation as well as relevant discussion have been summarized under following heads :

\section{Dry matter of weeds:}

The dry matter production of weeds were significantly highest in weedy check treatment and lowest in weed free treatment among all the weed control treatments. Different weed management practices significantly reduced the dry matter of weeds and minimum weed dry matter observed under preemergence application of pendimethalin @ $1.5 \mathrm{~kg} / \mathrm{ha}(2.01)$ 
more effective and superior in controlling the broad spectrum of annual grassy and broad leaved weeds closely followed by pendimethalin $1.0 \mathrm{~kg} / \mathrm{ha}$ (3.05)among herbicidal treatments and in cultural practices two hand weeding at 15 and 30 days after sowing(3.78) recorded minimum weed dry matter than rest of the treatments as compared to the weedy check treatment.

The pre-emergence application of pendimethalin gave significantly lower weed population and weed dry weight as compared to Imazethapyr and post-emergence application of quizalofop-p-ethly and fenoxyprop-p-ethly similar observations were recorded by Mishra and Bhanu (2006) (Table 1).

\section{Weed control efficiency:}

Weed control efficiency denotes the control of weeds in respective treatments shows lower weed count and better weed practices. Increased weed control efficiency and decreased weed population and weed dry matter were noticed with higher dose of herbicides. Weed free (97.06) condition recorded higher weed control efficiency among all the weed control treatments through out the crop growth stages. In case of chemical weed control treatments among all the weed control treatments at all the crop growth stages, result of pendimethalin as pre-emergence application gave the highest reduction in number and dry weight of weeds per square metre and better WCE was reported by Ahmed et al. (2008) in peanut crop. Pre-emergence application of pendimethalin @ $1.5 \mathrm{~kg} / \mathrm{ha}$ have higher weed control efficiency in black gram as compared to weedy check (Malliswari et al., 2008).

\section{Weed index:}

Among the weed management practices preemergence application of Pendimethalin @ $1.5 \mathrm{~kg} / \mathrm{ha}$ recorded minimum weed index $(20.46 \%)$. Better weed control in this treatments provided favorable condition for crop growth and less yield reduction than other treatments. Weedy check treatment recorded the maximum weed index (59.13\%) among all the treatments and Rao and Rao (2003) also reported weed index of $49 \%$ due to uncontrolled weed growth during the crop season.

\section{Grain yield :}

Weed management practices significantly improved the grain yield over weedy check. Uncontrolled weeds on an average reduced black gram yield by $45 \%$. Weed free treatment recorded significantly highest $(12.67 \mathrm{Q} /$

\begin{tabular}{|c|c|c|c|c|c|}
\hline Treatments & $\begin{array}{l}\text { Total weed } \\
\text { Population }\left(\mathrm{m}^{-2}\right) \\
\text { At harvest }\end{array}$ & $\begin{array}{l}\text { Weed dry } \\
\text { weight } \\
\left(\mathrm{g} / \mathrm{m}^{2}\right) \\
\text { At harvest }\end{array}$ & $\begin{array}{c}\text { Weed control } \\
\text { Efficiency } \\
(\%) \\
\text { At harvest }\end{array}$ & $\begin{array}{l}\text { Weed index } \\
(\%) \text { after } \\
\text { harvest }\end{array}$ & $\begin{array}{l}\text { Grain yield } \\
\left.\qquad(\mathrm{q} \mathrm{ha})^{-1}\right)\end{array}$ \\
\hline$T_{1}-$ Weed free & 2.39 & 0.47 & 97.06 & 0 & 12.67 \\
\hline $\mathrm{T}_{2}$-Weedy check & 65.44 & 15.98 & - & 59.13 & 5.14 \\
\hline $\mathrm{T}_{3}-2$ Hand weeding ( $15 f b 30$ DAS) & 27.40 & 3.78 & 76.35 & 26.77 & 9.31 \\
\hline $\mathrm{T}_{4}-2$ Hoeing (10 fb 20 DAS $)$ & 44.00 & 5.99 & 62.52 & 45.82 & 6.81 \\
\hline $\mathrm{T}_{5}$ - Imazethapyr at $50 \mathrm{~g} /$ ha PE (At sowing) & 38.62 & 5.00 & 68.71 & 52.18 & 6.11 \\
\hline $\mathrm{T}_{6}$ - Imazethapyr at $75 \mathrm{~g} /$ ha PE (At sowing) & 33.10 & 3.95 & 75.28 & 33.43 & 8.28 \\
\hline $\mathrm{T}_{7}$ - Pendimethalin at $1000 \mathrm{~g} /$ ha PE (At sowing) & 19.25 & 3.05 & 80.91 & 21.52 & 9.97 \\
\hline $\mathrm{T}_{8}$ - Pendimethalin at $1500 \mathrm{~g} /$ ha PE (At sowing) & 15.75 & 2.01 & 87.42 & 20.46 & 10.05 \\
\hline $\mathrm{T}_{9^{-}}$Fenoxyprop-p-ethyl at $100 \mathrm{~g} /$ ha POE ( $\left.15 \mathrm{DAS}\right)$ & 30.70 & 3.88 & 75.72 & 29.33 & 8.83 \\
\hline $\mathrm{T}_{10}$ - Fenoxyprop-p-ethyl at $125 \mathrm{~g} /$ ha POE ( $15 \mathrm{DAS}$ ) & 20.60 & 3.15 & 80.29 & 22.49 & 9.86 \\
\hline $\mathrm{T}_{11}$ - Quizalofop-p- ethyl at $50 \mathrm{~g} /$ ha POE ( $15 \mathrm{DAS}$ ) & 50.20 & 10.02 & 37.30 & 36.57 & 7.78 \\
\hline $\mathrm{T}_{12}$ - Quizalofop-p- ethyl at $75 \mathrm{~g} /$ ha POE ( $15 \mathrm{DAS}$ ) & 35.55 & 4.95 & 69.02 & 31.54 & 8.55 \\
\hline $\begin{array}{l}\mathrm{T}_{13} \text { - Imazethapyr at } 50 \mathrm{~g} / \text { ha PE fb Quizalofop-p- ethyl } \\
\text { at } 50 \mathrm{~g} / \text { ha POE ( At sowing fb } 15 \mathrm{DAS} \text { ) }\end{array}$ & 47.00 & 8.80 & 44.93 & 34.11 & 8.22 \\
\hline $\mathrm{SE}(\mathrm{m}) \pm$ & 2.31 & 0.45 & - & - & 0.86 \\
\hline C.D.at $5 \%$ - & 6.75 & 1.32 & - & - & 2.52 \\
\hline G.M. - & 33.08 & 5.46 & 65.81 & 31.8 & 8.58 \\
\hline
\end{tabular}


Kavita D. Rajput, J. P. Bholane, A.S. Latkar and V. M. Bhale

ha) grain yield among all the treatments and weedy check treatment recorded significantly lowest $(5.14 \mathrm{q} / \mathrm{ha})$ grain yield than rest of the weed control treatments. (Table 1) Similar results were recorded by Sharma et al. (1988). In herbicidal treatments, pre-emergence application of pendimethalin@1.5kg/ha recorded maximum (10.05 q /ha) yield among rest of the herbicidal treatments followed by PE application of pendimethalin @ $1.0 \mathrm{~kg} / \mathrm{ha}$ recorded $(9.97 \mathrm{q} / \mathrm{ha})$ grain yield and remaining herbicidal treatments bring at par with each other. These treatments controlled the weeds efficiently and thus resulted in significant increased in grain yield. Pre-emergence application of pendimethalin at $1.5 \mathrm{~kg} / \mathrm{ha}$ and $1.0 \mathrm{~kg} / \mathrm{ha}$ gave significantly higher seed yield of black gram as compared to weedy check, Imazethapyr, quizalofop-pethyl and fenoxyprop-p-ethyl. Above results are in accordance with the findings of Malliswari et al. (2008).

\section{Economics of weed management practices:}

\section{Gross monetary return:}

Highest gross monetary return was significantly recorded under weed free treatment (48410 Rs./ha) and lowest under weedy check treatment (21829 Rs./ha) among all the weed control treatments. In rest of the treatments, pre-emergence application of pendimethalin @ $1.5 \mathrm{~kg} /$ ha closely followed by pendimethalin @ 1.0 $\mathrm{kg} / \mathrm{ha}$ as PE application and post-emergence application of fenoxyprop-p-ethyl @ $0.125 \mathrm{~kg} / \mathrm{ha}$ were recorded maximum gross monetary return of black gram and superior to the rest of the treatments because these treatments were effective in controlling the weeds and increasing the yield and relative monetary returns of black gram (Table 2). But among all the weed control treatments, pre-emergence application of imazethapyr (a) $0.050 \mathrm{~kg} / \mathrm{ha}$ recorded significantly minimum relative monetary returns of blackgram except weedy check treatment due to its phyto-toxicity effect on black gram crop and its ineffectiveness in controlling the weeds.

\section{Net monetary returns:}

Net monetary returns were significantly recorded highest in weed free treatment (35356 Rs./ha) and lowest in weedy check treatment (14175 Rs./ha) among all the weed control treatments. In rest of the weed control treatments among chemical measures, pre-emergence application of pendimethalin@ $1.0 \mathrm{~kg} / \mathrm{ha}$ recorded significantly maximum net monetary returns of black gram and superior treatment over rest of the treatments which was closely followed by pendimethalin@1.5 kg/ ha as PE application and fenoxyprop-p-ethyl @ 0.125 $\mathrm{kg} /$ ha as post-emergence application (Table 2). Effective weed control with better seed yield resulted in higher gross monetary returns and net monetary returns in treatments of pre-emergence application of

\begin{tabular}{|c|c|c|c|c|}
\hline Treatments & $\begin{array}{c}\text { Gross monetary returns } \\
\left({ }^{\prime} \text { Rs. ha }{ }^{-1}\right)\end{array}$ & $\begin{array}{c}\text { Cost of cultivation } \\
\left(\text { Rs. ha }{ }^{-1}\right)\end{array}$ & $\begin{array}{c}\text { Net monetary returns } \\
\left(\text { 'Rs. ha }{ }^{-1}\right)\end{array}$ & B : C ratio \\
\hline$T_{1}-$ Weed free & 48410 & 13054 & 35356 & 3.71 \\
\hline $\mathrm{T}_{2}$-Weedy check & 21829 & 7654 & 14175 & 2.85 \\
\hline $\mathrm{T}_{3}-2$ Hand weeding ( 15 and $30 \mathrm{DAS}$ ) & 37061 & 12454 & 24607 & 2.98 \\
\hline $\mathrm{T}_{4}-2$ Hoeing (10 and $\left.20 \mathrm{DAS}\right)$ & 27977 & 8534 & 19443 & 3.28 \\
\hline $\mathrm{T}_{5}$ - Imazethapyr at $50 \mathrm{~g} /$ ha PE ( At sowing) & 25456 & 8714 & 16742 & 2.92 \\
\hline $\mathrm{T}_{6}$ - Imazethapyr at $75 \mathrm{~g} /$ ha PE (At sowing) & 33051 & 9064 & 23987 & 3.65 \\
\hline $\mathrm{T}_{7}$ - Pendimethalin at $1000 \mathrm{~g} / \mathrm{ha} \mathrm{PE}$ ( At sowing) & 39182 & 9612 & 29570 & 4.08 \\
\hline $\mathrm{T}_{8}$ - Pendimethalin at $1500 \mathrm{~g} / \mathrm{ha} \mathrm{PE}$ ( At sowing) & 39782 & 10414 & 29368 & 3.82 \\
\hline $\mathrm{T}_{9^{-}}$Fenoxyprop-p-ethyl at $100 \mathrm{~g} /$ ha POE ( $15 \mathrm{DAS}$ ) & 35329 & 9214 & 26115 & 3.83 \\
\hline $\mathrm{T}_{10}-$ Fenoxyprop-p-ethyl at $125 \mathrm{~g} / \mathrm{ha}$ POE ( $\left.15 \mathrm{DAS}\right)$ & 39016 & 9514 & 29502 & 4.10 \\
\hline $\mathrm{T}_{11}$ - Quizalofop-p- ethyl at $50 \mathrm{~g} /$ ha POE ( 15 DAS) & 30763 & 9214 & 21549 & 3.34 \\
\hline $\mathrm{T}_{12}$ - Quizalofop-p- ethyl at $75 \mathrm{~g} /$ ha POE ( 15 DAS) & 34282 & 9814 & 24468 & 3.49 \\
\hline $\begin{array}{l}\mathrm{T}_{13} \text { - Imazethapyr at } 50 \mathrm{~g} / \text { ha PE fb Quizalofop-p- ethyl } \\
\text { at } 50 \mathrm{~g} / \text { ha POE ( At sowing fb } 15 \text { DAS) }\end{array}$ & 32459 & 9914 & 22545 & 3.27 \\
\hline $\mathrm{SE}(\mathrm{m}) \pm$ & 2610 & - & 2610 & - \\
\hline C.D.at $5 \%$ - & 7620 & - & 7620 & - \\
\hline G.M. - & 34200 & 9782.31 & 24418 & 3.49 \\
\hline
\end{tabular}


pendimethalin at both concentrations. This is in conformity with Ramnathan and Chandrashekharan (1998) and Rathi et al. (2004).

Weed free check grave the highest net monetary returns as well as additional returns over the control followed by the herbicidal treatments. Above results in accordance with the finding of Yadav et al. (1997). It was observed that pre-emergence application of pendimethalin gave higher net monetary return as compared to weedy check. Similar results were obtained by Malliswari et al. (2008).

\section{Benefit : Cost ratio:}

Maximum benefit : cost ratio (B:C ratio) was obtained with post-emergence application (15 DAS) of fenoxyprop-p-ethyl @ $0.125 \mathrm{~kg} / \mathrm{ha}$ (4.10) and superior among all the weed control treatments closely followed by pendimethalin@1.0 kg/ha as pre-emergence application and fenoxyprop-p-ethyl@ @ $0.100 \mathrm{~kg} / \mathrm{ha}$ as a post-emergence application (Table 3). Among all the weed control treatments, pre-emergence application of imazethapyr @ $0.050 \mathrm{~kg} / \mathrm{ha}$ recorded minimum B:C ratio (2.92) except weedy check treatment due to its phytotoxicity effect to plant and ineffective in controlling the weeds which was effect on low seed yield level under this treatment.

Based on the relative gross monetary returns, Net monetary returns and Benefit:cost ratio can be recommended that effective weed management in black gram can be done with pre-emergence application of pendimethalin@ $1.5 \mathrm{~kg} / \mathrm{ha}$ and $@ 1.0 \mathrm{~kg} / \mathrm{ha}$ or postemergence application of fenoxyprop-p-ethyl @ 0.125 $\mathrm{kg} / \mathrm{ha}$.

\section{Conclusion:}

It can be concluded that the gross monetary returns (GMR) were significantly higher under Pendimethalin $1500 \mathrm{~g} \mathrm{ha}^{-1} \mathrm{PE}$ (39782) followed by Pendimethalin 1000 g ha-1 PE (39182). Net monetary returns (NMR) were the maximum with Pendimethalin $1000 \mathrm{~g} \mathrm{ha}^{-1} \mathrm{PE}$ (29570) (except, weed free). It was at par with Fenoxyprop-pethyl $125 \mathrm{~g} \mathrm{ha}^{-1}$ POE. Benefit : cost ratio was higher under Fenoxyprop-p-ethyl $125 \mathrm{~g} \mathrm{ha}^{-1} \mathrm{POE}(4.10)$ followed by Pendimethalin $1000 \mathrm{~g} \mathrm{ha}^{-1} \mathrm{PE}$. Among the weed control treatments, quizalofop-p-ethyl registered the lowest GMR, NMR and B:C ratio. Overall, weedy check recorded the lowest GMR, NMR and B:C ratio.

\section{REFERENCES}

Ahmed,Y.M., Mustafa,A.S., Reda, L.A., Khozimy,A.M. and Mosteh, Y. Y. (2008). Efficiency of the selected herbicides in controlling weeds and their side effects on peanut. J. Plant Protection Res., 48(3) : 355-363.

Ali, M., Pandey, R.K. and Rawat, C.R. (1982). Studies on intercropping and weed management in piqeonpea under dryland conditions. Madras. J. Agric. Sci., 69 : 474-478.

Gautam, K. C., Mani, V. S. and Sharma, R. K. (1975). Anote on efficiency, Selectivity and residual toxicity of some soil applied pesticide in black gram. Indian J. Weed Sci.7(1): 7274.

Gill, H. S. and Kumar, Vijay (1969). Weed index a new method for reporting with control trial. Indian J. Agron.,14(1): 96-98.

Malliswari, T., Reddy, M. P., Sagar, K.G. and Chandrika, V. (2008). Effect of irrigation on weed management practices on weed control and yield of blackgram. Indian J. Weed Sci., 40 $(1 \& 2): 85-86$.

Mishra, J. S. and Bhanu, C. (2006). Effect of herbicides on weeds, nodulation and growth of rhizobium in summer blackgram. Indian J. Weed Sci., 38(1\&2) : 150-153.

Ramanathan, S. P. and Chandrashekharan, B. (1998). Weed management in black gram (Phaseolus mungo). J. Indian Agron., 43 (2): 318-320.

Rao, A. S. and Rao, R. S. N. (2003). Bioefficacy of clodinafoppropargyl on Echinochloa spp. In black gram. Indian J. Weed Sci., 35 (3/4): 251-252.

Rathi, J. P. S., Tiwari, A. N. and Kumar, M. (2004). Integrated weed management in black gram. Indian J. Weed Sci., 36(3/4): 218-220.

Sharma, J. and Nayital, S. C. (1991). Crop-weed competition in maize+black gram intercropping system. Indian $J$. Agronomy, 36: 64-67.

Sharma, K. K. and Rajkhowa, D.J. (1988). Performance of herbicides for weed control in black gram. Pesticides, 22 (6): 39.

Vats, O. P. and Sawhney, J. S. (1981). Crop weed competition studies in black gram. Abstract of papers, Annual Conference of Indian Society of Weed Science, India. 8.

Yadav, R. P., Yadav, K.S. and Shrivastava, U. K. (1997). Integrated weed management in black gram. J. Indian Agron., 42 (1): 124-126.

Yadav, S. K., Singh, S. P. and Bhan, V. M. (1983). Weed control in chickpea. Tropical Pest Management, 29 (3) : 297-398.

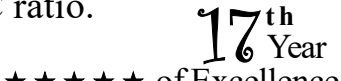

Internat. J. agric. Sci. $\mid$ Jan., $2021 \mid$ Vol. $17 \mid$ Issue $1 \mid 142-146$ 146 